\title{
Management of the Size of the Supply Under the Conditions of Inflation
}

\author{
Paweł Ślaski \\ Military University of Technology, Poland
}

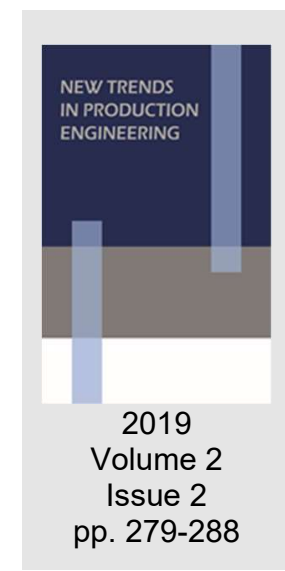

Date of submission to the Editor: 09/2019

Date of acceptance by the Editor: 11/2019

\section{INTRODUCTION}

In the second half of 2017, the Polish economy was in the expansion phase GDP dynamics reached the level of $5 \% \mathrm{y} / \mathrm{y}$, the highest since 2011, while inflation was 0.1 percentage point above the expectations. This arises from the stronger growth in food prices in the fourth quarter of 2017 due to a lower supply of some agricultural raw materials, mainly fruit, vegetables and dairy and fat products. The sharp increase in food prices in 2017 resulted from the lower availability of some raw materials and agricultural products (including fruit, butter, milk, eggs).

The analysis of the literature (Diewert, 1998; Pollak, 1998; Boskin, Dulberger, Gordon, Griliches, Jorgenson, 1998; Meyer and Zaman, 2019) explains that the most popular measure of inflation such as weighted average price of goods and services purchased by the average household is the CPI index.

CPI inflation in the projection horizon will grow and in 2018-2020 it will be above $2.5 \%$. The increase in CPI inflation in 2018-2020, in particular in core inflation, will be caused by the increase in cost and demand pressure in the Polish economy. Higher inflation will be influenced by the increase in wages projected in the projection horizon, which exceeds the dynamics of labour productivity. The acceleration of wage growth will be supported by the continued strong demand for labour from enterprises with limited labour supply. The impact of domestic factors on the rise in CPI inflation in 2018-2020 will be partially sustainable by the expected low level of import prices, resulting from the persistence of moderate price growth in the euro zone and the appreciation of the Polish zloty. According to the central path, food prices will increase by $3.3 \%$ in 2018 , by $2.9 \%$ in 2019 and by $3.2 \%$ in 2020 as compared to a $4.3 \%$ increase in 2017.

The aim of the paper is a development of a mathematical model of purchasing optimization, taking into account the $\mathrm{CPI}$ and the trade margin.

The following research methods were used to solve the research problem:

1. Model EOQ. 
2. Mathematical modelling.

3. Non-linear programming and GRG algorithm of SOLVER application.

The research problem was posed in the form of a question:

How to make optimal purchases of goods, taking into account the inflation rate on a selected example of a basket of goods, to minimize total inventory costs?

\section{OWN RESEARCH}

Own research was conducted on the example of a basket of consumer goods in 2012-2017. Based on data obtained from the Central Statistical Office (GUS), the share of the CPI (Consumer Price Index) of an individual basket components was analyzed (Figure 1).

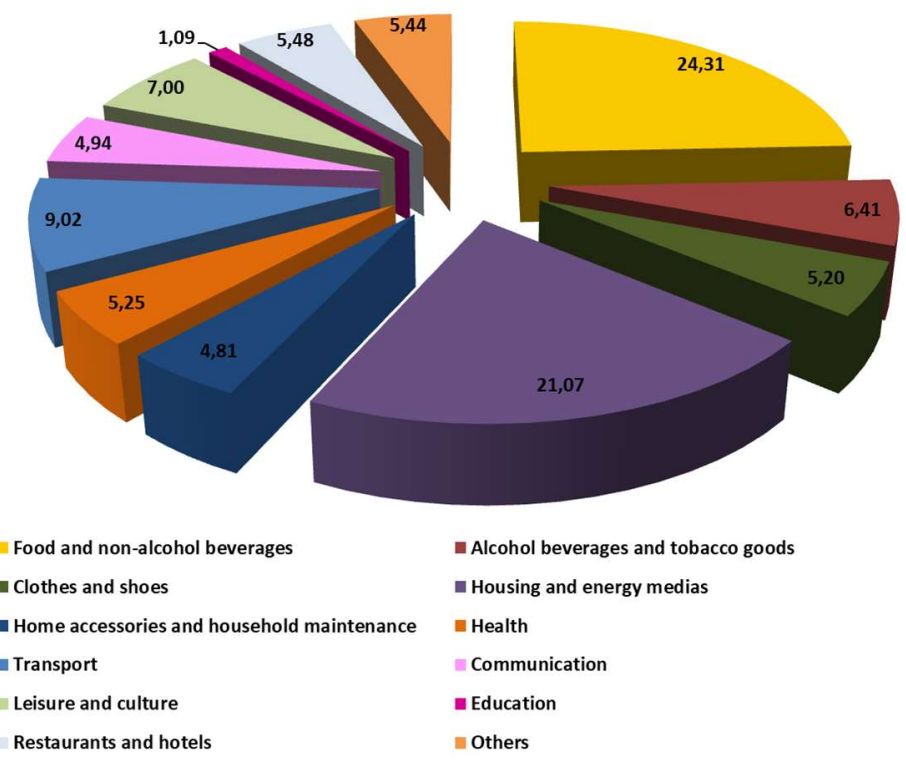

Source: Own study

Fig. 1 Summary of the basket of CPI goods in 2012-2017 (share in \%)

Due to the highest percentage share of CPI of food goods $(24.31 \%)$, this group was included in further studies.

Table 1 and Figure 2 show the volatility of the CPI in 2012-2017 on a monthly basis along with the analysis of the linear trend.

Table 1 The size of the CPI in 2012 - 2017 and the average size of individual months

\begin{tabular}{|l|r|r|r|r|r|r|r|}
\hline & \multicolumn{1}{|c|}{$\mathbf{2 0 1 7}$} & \multicolumn{1}{c}{$\mathbf{2 0 1 6}$} & \multicolumn{1}{c}{$\mathbf{2 0 1 5}$} & \multicolumn{1}{c}{$\mathbf{2 0 1 4}$} & \multicolumn{1}{c}{$\mathbf{2 0 1 3}$} & \multicolumn{1}{c}{$\mathbf{2 0 1 2}$} & \multicolumn{1}{c|}{ Average } \\
\hline January & 103,3 & 100,1 & 96,1 & 101,6 & 103,5 & 104,4 & 101,50 \\
\hline February & 104,3 & 100,4 & 95,9 & 101,8 & 102,6 & 104,5 & 101,58 \\
\hline March & 103,4 & 100,9 & 96,2 & 101,4 & 101,6 & 103,6 & 101,18 \\
\hline April & 103 & 100,7 & 97,3 & 100,5 & 101,8 & 102,9 & 101,03 \\
\hline May & 103,9 & 100,9 & 97,6 & 99,2 & 101,7 & 102,5 & 100,97 \\
\hline June & 103,9 & 101,1 & 98,1 & 99,1 & 100,8 & 105,4 & 101,40 \\
\hline July & 104,7 & 101,2 & 98,2 & 98,2 & 102,7 & 105,1 & 101,68 \\
\hline August & 104,6 & 101,4 & 99,3 & 97,7 & 102,8 & 105,4 & 101,87 \\
\hline September & 105,3 & 100,4 & 99,9 & 97,7 & 102,9 & 105,4 & 101,93 \\
\hline October & 105,8 & 100,4 & 100,5 & 97,6 & 102,2 & 104,9 & 101,90 \\
\hline November & 106,5 & 101,3 & 100,2 & 97,3 & 101,9 & 104 & 101,87 \\
\hline December & 105,8 & 102,7 & 100 & 96,5 & 101,7 & 104 & 101,78 \\
\hline
\end{tabular}

Source: Own study 
The trend analysis carried out (Figure 2) confirms the increase in the CPI in subsequent years.

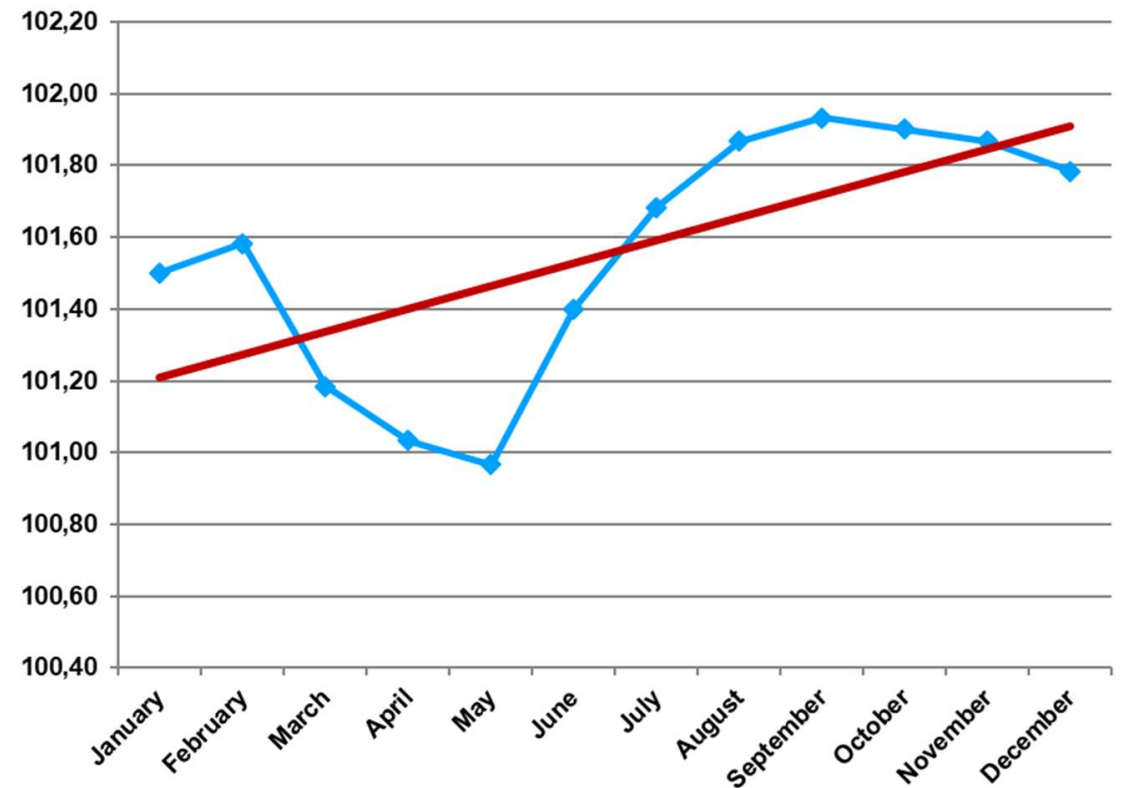

Fig. 2 Variability of the CPI index in 2012-2017

Source: Own study on the monthly average with the analysis of the linear trend

Rising prices of goods, especially food, prompted the author of the paper to conduct an analysis related to the impact of the CPI on the volume of goods orders (Moon, Lee, 2000). To determine the optimal supply quantities, the commonly used rule of Economics Order Quantity - EOQ was used (Kun-Jen Chung, 1998; Eksler et. al., 2019). EOQ is a special size of the order, at which the total costs of ordering and maintaining stocks, eg. on an annual scale are minimal (Tajbakhsh, Lee, Zolfaghari, 2010; Huang, 2007). This rule is related to R.H. Wilson (Eroglu, Ozdemir, 2007; Lin, 2019; Dewi et. al., 2019; Chanda and Kumar, 2019) (1):

$$
E O Q=\sqrt{\frac{2 \cdot P \cdot \mathrm{ucc}}{\mathrm{ucm}}}
$$

where:

$P$ - annual demand,

ucc - unit cost of creating supplies,

ucm - the unit cost of maintaining the stock.

The economic order quantity (EOQ) is the result of a deterministic ordering model and balances the total annual costs of ordering and maintaining goods at the given time (Figure 3).

National and foreign literature describes a number of EOQ applications for solving complex decision problems, both in deterministic cases and in a probabilistic environment. (Tajbakhsh, Lee Zolfaghari, 2010; Rezaei, Salimi, 2012; Chua, Chung, Lanc, 1998; Karimi et. al.,2019; Alfares \& Ghaithan, 2019) present the cases of determining optimal quantities based on the EOQ rule to ensure reliability of supply. In turn (Krzyżaniak, 2008; Pando et. al., 2019; Kundu 
et. al., 2019) describing the essence of the stochastic model of ordering the socalled Reorder Point (Reorder Level) indicates EOQ as a fixed delivery amount (Michalski, 2008).

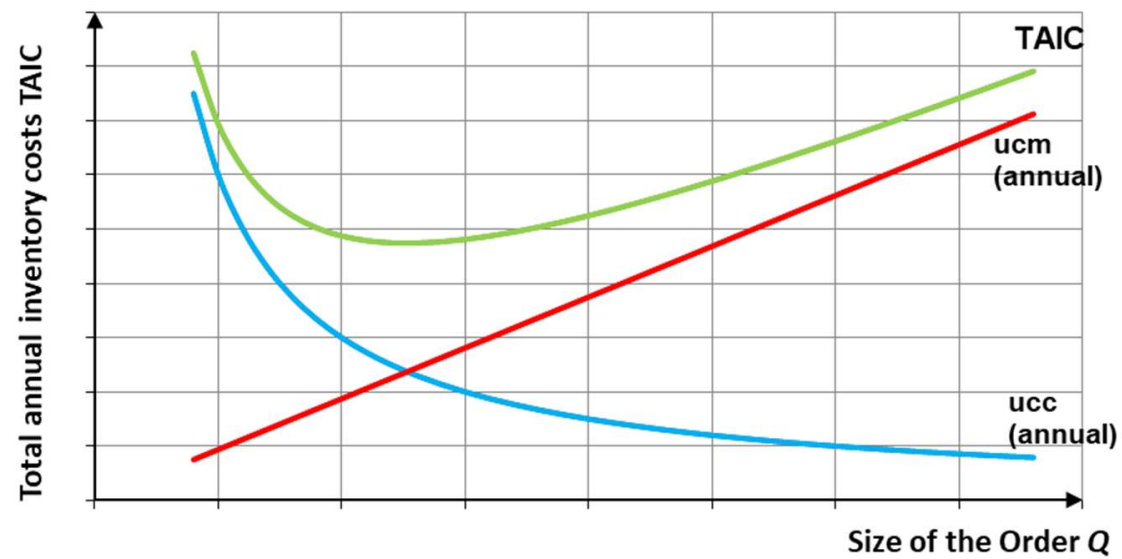

Fig. 3 Graph of total annual inventory costs

Source: Own study based on: Z. Sarjusz-Wolski, Supply Management Strategy, Agencja Wydawnicza Planet, Warsaw, 1998, p. 91

Considering the production process, (Sarjusz-Wolski, 2000; Krommyda et. al., 2019) uses the skin to determine the optimal production batch. Worth mentioning is also the effect of scale in the ordering process. (Sarjusz-Wolski 2000) describes the benefits of larger deliveries related to obtaining price rebates. Whereas (Krzyżaniak, 2008) takes into account the EOQ model as the basic assumption for two cases of inventory control of assortment groups (Vujošević et.al.,1996). Cinzia, (2016), Tripathy \& Pattnaik (2011), use the above model in the theory of fuzzy sets to determine optimal deliveries.

\section{THE OPTIMAL ORDER SIZE MODEL, INCLUDING THE CPI}

The logistics chain was analyzed in order to include: a production and dairy company, a group of wholesalers and retail stores. It was also assumed that the CPI for a selected product from the basket of food products is $3.5 \%$.

The model considered two purchases:

1. Changes in sales prices are made continuously in line with the inflation rate.

2. One-time adjustment of sales prices to the purchased party of goods.

\section{The structure of the model}

The model in both cases consists of three stages:

1. Determining the purpose of the model according to the clients' requirements.

2. Designing a process that meets the expectations of recipients (customers).

3. Model verification.

The general form of the objective function is as follows (2):

$$
\operatorname{TAIC}(Q)=u c c(\text { annual })+u c m(\text { annual }) \rightarrow \min
$$

So in the first case, the objective function is (3):

$$
\operatorname{TAIC}^{\prime}(Q)=\frac{Q}{2} \cdot\left(1-\frac{i}{u_{r}}\right) \cdot c \cdot u_{r}+\frac{P}{Q} \cdot u c c \rightarrow \min
$$


In the second case, the objective function takes the form (4):

$$
\operatorname{TAIC}^{\prime \prime}(Q)=\frac{Q}{2} \cdot\left(1+\frac{i \cdot f}{u_{r}}\right) \cdot c \cdot u_{r}+\frac{P}{Q} \cdot u c c \rightarrow \min
$$

where:

TAIC $(\mathrm{Q})$ - total annual inventory costs

ucc (annual) - total costs of creating inventories (annually)

ucm (annual) - total costs of maintaining inventories (annually)

$\mathrm{Q}$ - delivery quantity

$\mathrm{i}-$ inflation index

$f$ - trade margin

ur - coefficient of the annual cost of maintaining stocks, whose basic component is the interest rate on bank loans

$c-$ the purchase price of the item unit

ucc - unit cost of creating supplies

$\mathrm{P}-$ demand (annual needs)

The second stage consists in determining the extreme of TAIC' and TAIC" functions and determining optimal shopping parties $Q_{o p t}^{\prime} i Q_{o p t}^{\prime \prime}(5)$ :

$$
\frac{d T A I C^{\prime}}{d Q}=0 ; \frac{d T A I C^{\prime \prime}}{d Q}=0
$$

For the first case $\left(6,6^{\prime}\right)$ :

Therefore:

$$
\frac{d T A I C^{\prime}}{d Q}=\frac{1}{2} \cdot\left(1-\frac{i}{u_{r}}\right) \cdot c \cdot u_{r}-\frac{P}{Q^{2}} \cdot u c c=0
$$

$$
Q^{\prime}{ }_{\text {opt }}=\sqrt{\frac{2 \cdot P \cdot u c c}{c \cdot\left(u_{r}-i\right)}}
$$

Or:

$$
Q^{\prime}{ }_{\text {opt }}=Q_{\text {opt }} \cdot \sqrt{\frac{1}{\left(1-\frac{i}{u_{r}}\right)}}
$$

while for the second case $\left(7,7^{\prime}\right)$ :

$$
\frac{d T A I C "}{d Q}=\frac{1}{2} \cdot\left(1+\frac{i \cdot f}{u_{r}}\right) \cdot c \cdot u_{r}-\frac{P}{Q^{2}} \cdot u c c=0
$$

Therefore:

$$
Q{ }^{\prime o p t}=\sqrt{\frac{2 \cdot P \cdot u c c}{c \cdot\left(u_{r}+i \cdot f\right)}}
$$

Or:

$$
Q^{\prime \prime}{ }_{o p t}=Q_{o p t} \cdot \sqrt{\frac{1}{\left(1+\frac{i \cdot f}{u_{r}}\right)}}
$$

\section{MODEL VERIFICATION}

Model verification was performed in the Excel spreadsheet using the Solver addition. The algorithm of Generalized Reduced Gradient (GRG2) non-linear optimization, developed by Leon Lasdon from the University of Texas at Austin and Allan Waren from the State University of Cleveland, was used for the solution. 
Solving a problem in the Solver application consists of three stages (Ślaski, 2017):

Stage 1, Development of a spreadsheet with input data (Figure 4).

Optimum size of the order including the CPI model
\begin{tabular}{|r|c|c|c|r|c|}
\hline ucc & $\boldsymbol{i}$ & $\boldsymbol{u}_{\boldsymbol{r}}$ & $\boldsymbol{f}$ & $\boldsymbol{c}$ & $\boldsymbol{P}$ \\
\hline 70 & $3,50 \%$ & $10 \%$ & $15 \%$ & 11 & 7500 \\
\hline
\end{tabular}

Source: Own study

Fig. 4 Model input data

The aim of this stage is to enter the input data into the spreadsheet table, which will be entered in the next stage of the Solver application dialog.

Stage 2, Development of the objective function and input of input data to the Solver dialog box - Parameters, Fig. 5.

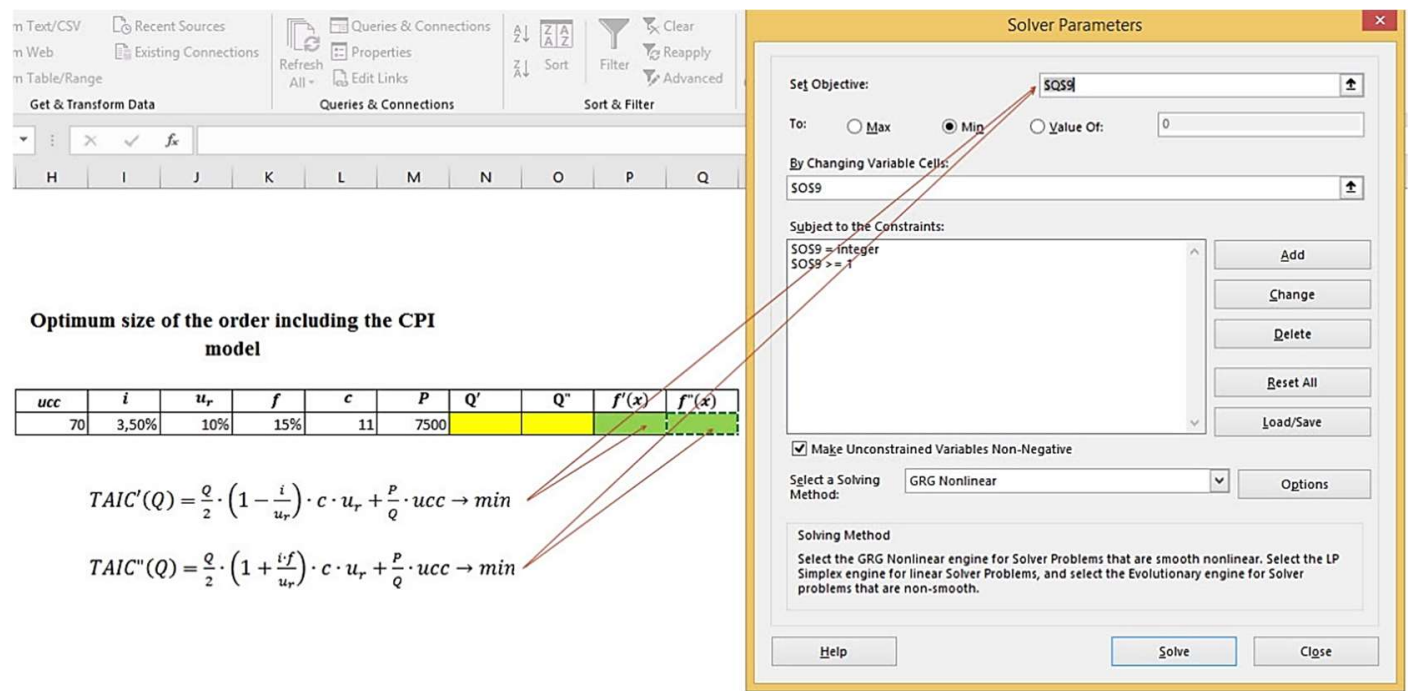

Source: own study

Fig. 5 Solver-parameters dialog box

In this stage, the basic task is to enter input data into the Solver-parameters dialog box. Attention should be paid to the following elements:

1. Setting the goal to a minimum,

2. Selecting the decision variable $Q$,

3. Typing restrictions,

4. Choosing a method to solve the problem.
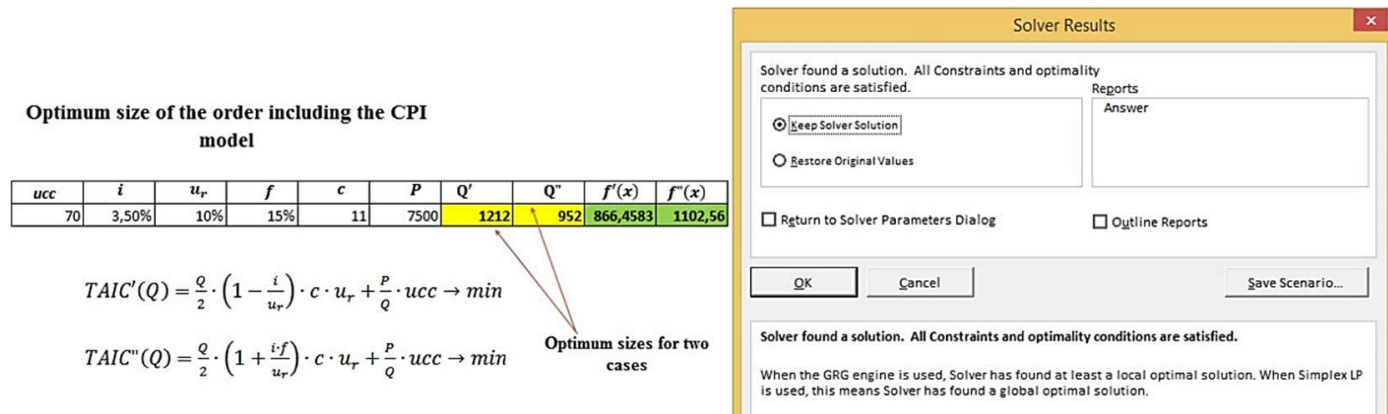

Source: own study

Fig. 6 Results of the Solver addition 
Stage 3, solving the task and determining optimal sizes.

This stage presents the results of the Solver addition Figure 6. For the input data received, the optimal delivery quantities and minimum inventory costs for the described ordering methods were obtained.

\section{RISK ANALYSIS}

Due to the complexity of the problems presented in the model, a risk analysis should be performed. The risks in this case relate to future uncertain events that, if they occur, will affect the purpose of the developed model.

The risk analysis has been developed based on the PRINCE 2 project management methodology and includes: identification of the cause of risk, reaction to risk, risk management procedure and risk assessment. Figure 7 and Table 1 present the risk management procedure and the register of basic risks along with their reaction to their occurrence.

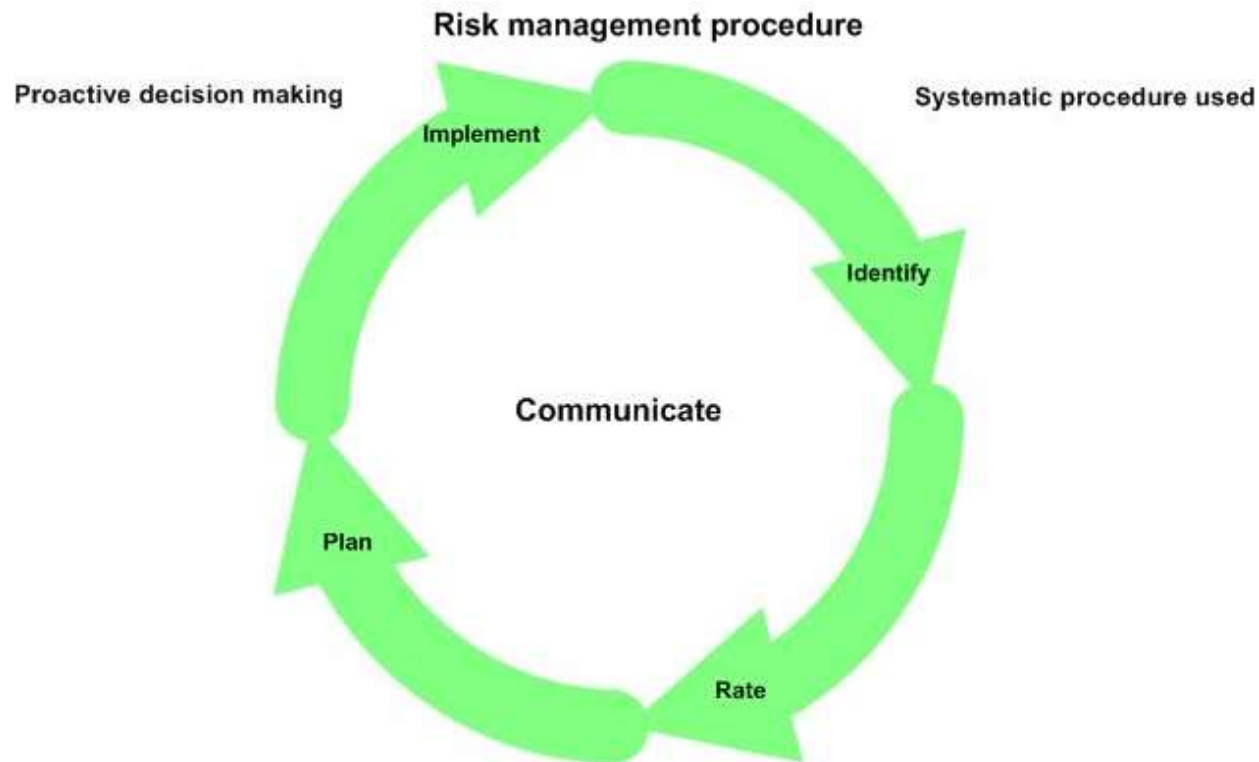

Source: Own

Fig. 7 Risk management procedure

Table 1 Register of basic risks

\begin{tabular}{|c|l|l|l|l|}
\hline No & $\begin{array}{l}\text { The reason } \\
\text { of the risk }\end{array}$ & $\begin{array}{l}\text { It can cause an } \\
\text { uncertain event }\end{array}$ & $\begin{array}{l}\text { Which may } \\
\text { affect the aim }\end{array}$ & \multicolumn{1}{|c|}{$\begin{array}{c}\text { Reaction } \\
\text { for the risk }\end{array}$} \\
\hline 1 & $\begin{array}{l}\text { Large } \\
\text { fluctuations } \\
\text { in the CPI } \\
\text { inflation rate }\end{array}$ & $\begin{array}{l}\text { Uneconomic } \\
\text { purchase volumes }\end{array}$ & $\begin{array}{l}\text { Increase } \\
\text { in purchase } \\
\text { costs }\end{array}$ & $\begin{array}{l}\text { Developing a mathematical model } \\
\text { of purchasing optimization, taking into } \\
\text { account the CPI and the trade margin }\end{array}$ \\
\hline 2 & $\begin{array}{l}\text { Suboptimal } \\
\text { inventory } \\
\text { management }\end{array}$ & $\begin{array}{l}\text { Excessive costs } \\
\text { of supplies and } \\
\text { maintenance } \\
\text { of stocks }\end{array}$ & $\begin{array}{l}\text { Lowering } \\
\text { customer } \\
\text { service } \\
\text { standards }\end{array}$ & Application of the EOQ model \\
\hline 3 & $\begin{array}{l}\text { Lack or } \\
\text { incorrect } \\
\text { verification of } \\
\text { the eveloped } \\
\text { model }\end{array}$ & $\begin{array}{l}\text { The emergence of } \\
\text { systematic errors } \\
\text { in model }\end{array}$ & $\begin{array}{l}\text { Excessive } \\
\text { costs of } \\
\text { supplies and } \\
\text { maintenance } \\
\text { of stocks }\end{array}$ & Application of non-linear programming \\
and GRG algorithm of SOLVER application
\end{tabular}

Source: Own based on PRINCE 2 (Foundation, Warszawa, WAT, 2013) 
The project risk management process recommends 5 steps: Identify, Rate, Plan, Implement and Communicate (Bannerman 2008; Tomanek, Juricek 2015).

\section{CONCLUSIONS}

The obtained results (Fig. 6) are approx. 24\% more in the first case and approx. $3 \%$ less - in the second case the economic value of delivery, which after the designation from the formula (1) on the EOQ is $977 \mathrm{pcs}$. These figures are due to the following reasons. In the first case, changes in the sales price were made continuously in line with the inflation rate. Therefore, buying a larger batch of goods than the resulting EOQ generally means that the income will be reduced by a lower purchase value. In the second case, it is better to buy smaller batches, because it is characterized by a one-off adjustment of sale prices to the entire purchased lot of goods. Purchases made in smaller batches cause faster consumption, and thus a higher basis for calculating the trade margin.

Application for verification of the Solver application model enables flexible reaction to changes in the $\mathrm{CPI}$ index as well as prices of purchased goods, thanks to which different scenarios for ordering goods in the logistics chain can be developed.

\section{REFERENCES}

Alfares HK., Ghaithan AM. (2019). EOQ and EPQ Production-Inventory Models with Variable Holding Cost: State-of-the-Art Review. Arabian Journal for Science and Engineering. Volume: 44 Issue: 3.

Bannerman, P.L.(2008). Risk and risk management in software projects: A reassessment. American Economic Journal-Microeconomics. No 81.

Boskin M. J., Dulberger E. R, Gordon R. J.(1998). Griliches Zvi, and Jorgenson Dale W. (1998).Consumer Prices, the Consumer Price Index, and the Cost of Living. Journal of Economic Perspectives. Volume 12. No 1.

Chua P, Chung Kun-Jen, Shaw-Ping Lanc. (1998). Economic Order Quantity of deteriorating items under permissible delay in payments. Computers \& Operations Research. Volume 25, Issue 10.

Cinzia M. (2016). An EOQ model for perishable products with fixed shelf life under stochastic demand conditions. European Journal of Operational Research 255. p. 388-396.

Chanda U., Kumar A. (2019). Optimization of EOQ Model for New Products Under Multi-Stage Adoption Process. International Journal of Innovation and Technology Management. Volume: 16 Issue: 2.

Chung Kun-Jen. (1998). A theorem on the determination of Economic Order Quantity under conditions of permissible delay in payments. Computers \& Operations Research. Volume 25, Issue 1.

Dewi EK., Dahlui M., Chalidyanto D., Rochmah TN. (2019). Achieving cost-efficient management of drug supply via Economic Order Quantity and minimum-maximum stock level. Expert Review of pharmacoeconomics \& outcomes research.

Eksler L., Aviram R., Elalouf A., Kamble A. (2019). An EOQ model for multiple products with varying degrees of Substitutability.Economics-The Open Access OpenAssessment E-journal. volume: 13.

Eroglu A, Gultekin O. (2007). An Economic Order Quantity model with defective items and shortages. International Journal of Production Economics. Volume 106, Issue 2.

Diewert, W. E. (1998). Index Number Issues in the Consumer Price Index. Journal of Economic Perspectives. Volume 12, No 1. 
Huang Yung-Fu. (2007). Economic Order Quantity under conditionally permissible delay in payments. European Journal of Operational Research.

Karimi M., Sadjadi SJ., Bijaghini AG. (2019). An Economic Order Quantity for deteriorating items with allowable rework of deteriorated products. Journal of Industrial and Management Optimization, volume: 15 issue: 4.

Krommyda IP., Skouri K., Lagodimos AG. (2019). A unified EOQ model with financial constraints and market tolerance. Applied Mathematical Modelling. Volume: 65.

Kundu A., Guchhait P., Panigrahi, G., Maiti M. (2019).An EOQ model for deteriorating item with promotional effort and credit linked demand. European Journal of Industrial Engineering. Volume: 13 Issue: 3.

Lin SSC. (2019). Note on "The derivation of EOQ/EPQ inventory models with two backorders costs using analytic geometry and algebra". Applied Mathematical Modelling. volume: 73.

Meyer B., Zaman S. (2019). The usefulness of the median CPI in Bayesian VARs used for macroeconomic forecasting and policy. Empirical Economics. Volume: 57. Issue: 2.

Michalski G. (2008). Value-based Inventory Management, Romanian Journal of Economic Forecasting.

Moon I, Lee S. (2000). The effects of inflation and time-value of money on an economic order quantity model with a random product life cycle. European Journal of Operational Research.

Pando V., San-Jose LA., Sicilia J. (2019). Profitability ratio maximization in an inventory model with stock-dependent demand rate and non-linear holding cost. Applied Mathematical Modelling. Volume: 66.

Pollak R. A. (1998). The Consumer Price Index: A Research Agenda and Three Proposals. Journal of Economic Perspectives. Volume 12, No 1.

Rezaei J, Negin S. (2012). Economic Order Quantity and purchasing price for items with imperfect quality when inspection shifts from buyer to supplier. International Journal of Production Economics.

Tajbakhsh M., Chi-Guhn L., Zolfaghari S. (2010). Sole sourcing in EOQ models with Binomial yield. Journal of Purchasing and Supply Management. Volume 16, Issue 3.

Tomanek M., Juricek J. (2015). Project risk management model based on Prince2 and scrum frameworks. International Journal of Software Engineering \& Applications (IJSEA).Vol.6, No.1.

Tripathy P. K, Pattnaik M. (2011). A Fuzzy EOQ Model with Reliability and DemandDependent Unit Cost. International Journal of Contemporary Mathematical Sciences. Vol. 6, No. 30.

Vujošević M., Petrović D., Petrović R. (1996). EOQ formula when inventory cost is fuzzy. International Journal of Production Economics Volume 45, Issues 1-3, 1, Pages 499-504.

Krzyżaniak S. (2002). Basics of Inventory Management in Examples. Poznań: Biblioteka Logistyka, ILiM.

Sarjusz-Wolski Z. (1998). Supply Management Strategy. Warszawa: Agencja Wydawnicza Planet.

Ślaski P. (2017). Inventory Management in Logistic Systems. Warszawa: WAT. 
Abstract.

The publication describes two ways of shopping, taking into account the CPI (Consumer Price Index) inflation rate. In the first case, changes in the sales price are made in a continuous manner in accordance with the inflation rate, and therefore it is better to make larger purchases. In the second case, it is better to carry out smaller purchases, because it is characterized by one-time adjustment of sales prices to the entire purchased a lot of goods. Both cases were verified based on the Solver tool, using non-linear, integer-based optimization. The final result was to determine the optimal purchase quantities with the minimum inventory costs.

Keywords: CPI index, EOQ, Solver application, purchase optimization 